\title{
Evaluation and Coordinated Development Measurement of the Construction of Marine Ecological Civilization in Coastal Areas-Taking Shandong Province, China as an Example
}

\author{
Jun Ma1,2 \\ ${ }^{1}$ School of Public Affairs, University of Science and Technology of China, Hefei, China \\ ${ }^{2}$ Xindu Primary School, Economic and Technological Development Zone, Weihai, China \\ Email: mary3180robert@163.com
}

How to cite this paper: Ma, J. (2020). Evaluation and Coordinated Development Measurement of the Construction of Marine Ecological Civilization in Coastal AreasTaking Shandong Province, China as an Example. Journal of Geoscience and Environment Protection, 8, 37-54. https://doi.org/10.4236/gep.2020.83004

Received: February 6, 2020

Accepted: March 20, 2020

Published: March 23, 2020

Copyright $\odot 2020$ by author(s) and Scientific Research Publishing Inc. This work is licensed under the Creative Commons Attribution International License (CC BY 4.0).

http://creativecommons.org/licenses/by/4.0/ (c) (i) Open Access

\begin{abstract}
This paper selected 25 evaluation indexes from the three aspects of marine ecological economy, marine ecological environment and marine ecological society to construct an evaluation index system of the construction of coastal marine ecological civilization, using the analytic hierarchy process (AHP) and entropy value method to determine evaluation index weights, and measured the construction level of marine ecological civilization in Shandong Province during the period of 2006-2016. The results showed that the construction level of marine ecological civilization in Shandong Province during 2006-2016 as a whole is on the rise. In terms of the increase of the scores of each subsystem, the development of marine ecological society increased the most, followed by the development of marine ecological economy, while the development of marine ecological environment was relatively slow. This paper also analyzed the coordinated development level of the paired subsystems such as the marine ecological economy plus marine ecological environment, marine ecological society plus marine ecological environment and marine ecological economy plus marine ecological society in Shandong Province during the period of 2006-2016 by using the coupling coordination analysis model. The results showed that the level of coordinated development between the three pairs of subsystems has basically gone through the development process from low coordination to moderate coordination, and finally to high coordination.
\end{abstract}

\section{Keywords}

Marine Ecological Civilization, Evaluation Index System, Coordinated Development, Empirical Analysis 


\section{Introduction}

The ocean is rich in energy and abundant in resources, and the marine economy has increasingly become a focus of economic competition among various countries and regions. However, along with the vigorous development of the marine economy, the balance between marine development and marine environmental protection is gradually losing. Ecological environment problems such as the sharp decline of marine biodiversity, marine environmental pollution and frequent marine disasters are becoming more and more frequent in recent years. This has seriously affected the healthy and orderly development of the economy and the society in coastal areas. In 2007, the Chinese government first listed ecological civilization construction as a new requirement for China to build a moderately prosperous society in all aspects. In 2012, the Chinese government attached equal importance to ecological progress with economic, political, cultural, and social progress, and ecological progress has been included in the "five-in-one" plan for advancing the cause of socialism with Chinese characteristics. As an important part of the construction of ecological civilization, the construction of marine ecological civilization has also attracted the attention of academic circles.

Liu Jiazhen (2007) pointed out that human sustainable development will rely more and more on marine resources. Therefore, the rational use of marine resources and the harmonious development of marine ecology have strategic significance especially for national resource security, economic security and even national defense security. Chen Jianhua (2009) believed that the construction of marine ecological civilization is an inevitable requirement for achieving scientific, coordinated and sustainable development of economy and society. Chen Fenggui et al. (2014) attributed the content of marine ecological civilization to the sustainable development of marine ecosystems and the sustainable development of human society. Relevant research on the evaluation of the construction of marine ecological civilization has only received the attention of Chinese scholars in recent years. Qin Weishan et al. (2016) constructed a level measurement index system for the construction of marine ecological civilization cities around the Bohai Sea from the six aspects of marine ecology, marine resources, marine environment, marine economy, marine culture and marine system. Sun Qian et al. (2017) adopted a multi-factor comprehensive evaluation method to construct a marine ecological civilization performance evaluation index system with twenty indexes from the five aspects of marine resources, marine environment, marine economy, marine culture and marine system. Sun Jianfeng et al. (2018) selected 29 specific indexes from the five aspects of marine resource endowment, marine ecological environment, marine economic development, marine culture construction and marine system management, and established an evaluation index system for marine ecological civilization in coastal cities. Du Yan et al. (2019) selected 32 indexes from the five aspects of marine economic operation, marine resource endowment, marine ecological environment, marine manage- 
ment system and marine culture and science, and constructed an evaluation index system for the construction of national demonstration area of marine ecological civilization.

It can be seen that the current research targets for the evaluation of the construction of marine ecological civilization are mostly concentrated in cities, and there are few provincial-level researches aiming for a larger regional scale. In addition, the construction of ecological civilization must achieve coordinated development of economy, environment and society, but few studies have evaluated the degree of coordinated development of these three subsystems. In this regard, the second part of this paper will take Shandong Province as the research object, construct an evaluation index system from three aspects: marine ecological economy, marine ecological environment, and marine ecological society; then conduct an empirical analysis on the evaluation of marine ecological civilization construction in Shandong Province, use coupling coordination model to analyze the coupling degree between the three subsystems of marine ecological economy, marine ecological environment and marine ecological society in third part of paper. Research conclusions in the fourth part of the article explore the coordination level of the "economy-environment-society" development in the construction of regional marine ecological civilization.

\section{Construction of Evaluation Index System}

The construction of the evaluation index system consists of two parts: the content of the evaluation indexes and the weight of the evaluation indexes.

\subsection{Evaluation Indexes, Data Sources and Standardization}

This research believes that the construction of marine ecological civilization is to maintain the balance of marine ecological environment by the development of marine economy, to promote the greater progress of marine economic development through the benign ecological cycle of marine environment, and to achieve a new situation of harmony and common prosperity featuring rapid development of the marine economy, continuous improvement of the marine environment quality and ongoing enhancement of the marine social support capacity. Based on the definition of this concept and the principles of comprehensive evaluation index construction such as integrity, operability, hierarchy and dynamics, this research constructed an evaluation index system for the construction of regional marine ecological civilizations containing 25 evaluation indexes from the three aspects of marine ecological economy, marine ecological environment and marine ecological society (as shown in Table 1).

This research conducted an empirical study with Shandong Province as the research object. Considering the availability of the data, the time range for data collection in this research was 2006-2016. Specific data sources are: China Ocean Statistical Yearbook (2007-2017), China's Coastal Water Environment Bulletin (2006-2016), Shandong Statistical Yearbook (2007-2017), Shandong Tourism 
Table 1. Evaluation index system and index weight of the construction of marine ecological civilization.

\begin{tabular}{|c|c|c|c|c|c|c|}
\hline \multirow[b]{2}{*}{$\begin{array}{l}\text { First-Level } \\
\text { Index }\end{array}$} & \multirow[b]{2}{*}{$\begin{array}{l}\text { Second-Level } \\
\text { Index }\end{array}$} & \multirow[b]{2}{*}{$\begin{array}{l}\text { Third-Level } \\
\text { Index }\end{array}$} & \multirow[b]{2}{*}{ Index Property } & \multicolumn{3}{|c|}{ Index Weight } \\
\hline & & & & AHP & $\begin{array}{l}\text { Entropy Evaluation } \\
\text { Method }\end{array}$ & Final Weight \\
\hline \multirow{7}{*}{$\begin{array}{c}\text { Marine } \\
\text { Ecological } \\
\text { Economy (A) }\end{array}$} & \multirow{3}{*}{$\begin{array}{l}\text { Scale and } \\
\text { Structure } \\
\quad(\mathrm{A} 1)\end{array}$} & A11 Marine GDP & Positive Index & 0.0582 & 0.0434 & 0.0508 \\
\hline & & A12 Marine GDP Proportion & Positive Index & 0.0404 & 0.0427 & 0.0416 \\
\hline & & A13 Tertiary Industry Proportion & Positive Index & 0.1680 & 0.0915 & 0.1298 \\
\hline & \multirow{5}{*}{$\begin{array}{l}\text { Production } \\
\text { Activity } \\
\text { (A2) }\end{array}$} & A21 Marine Fishing Production & Positive Index & 0.0098 & 0.0647 & 0.0373 \\
\hline & & A22 Aquaculture Production & Positive Index & 0.0273 & 0.0526 & 0.0400 \\
\hline & & A23 Cargo Throughput of Port & Positive Index & 0.0324 & 0.0389 & 0.0357 \\
\hline & & A24 Number of Tourists & Positive Index & 0.0638 & 0.0440 & 0.0539 \\
\hline \multirow{9}{*}{$\begin{array}{l}\text { Marine } \\
\text { Ecological } \\
\text { Environment } \\
\text { (B) }\end{array}$} & & B11 Wastewater Quantity & Inverse Index & 0.0400 & 0.0327 & 0.0364 \\
\hline & \multirow{5}{*}{$\begin{array}{l}\text { Pollutant } \\
\text { Emission } \\
\quad \text { (B1) }\end{array}$} & B12 COD & Inverse Index & 0.0400 & 0.0212 & 0.0306 \\
\hline & & B13 Petroleum & Inverse Index & 0.0400 & 0.0164 & 0.0282 \\
\hline & & B14 Ammonia-Nitrogen & Inverse Index & 0.0400 & 0.0324 & 0.0362 \\
\hline & & B15 Total Phosphorus & Inverse Index & 0.0400 & 0.0382 & 0.0391 \\
\hline & & $\begin{array}{l}\text { B21 Proportion of Category I and II } \\
\text { Water Quality }\end{array}$ & Inverse Index & 0.0373 & 0.0294 & 0.0334 \\
\hline & \multirow[t]{4}{*}{$\begin{array}{l}\text { Quality of } \\
\text { Seawater } \\
\text { (B2) }\end{array}$} & $\begin{array}{l}\text { B22 Proportion of Four Inferior } \\
\text { Water Quality }\end{array}$ & Inverse Index & 0.0646 & 0.0502 & 0.0574 \\
\hline & & B23 Area of Red Tide & Inverse Index & 0.0491 & 0.0233 & 0.0362 \\
\hline & & B24 Actual Coverage of Green Tide & Inverse Index & 0.0491 & 0.0345 & 0.0418 \\
\hline \multirow{8}{*}{$\begin{array}{l}\text { Marine } \\
\text { Ecological } \\
\text { Society } \\
\text { (C) }\end{array}$} & & $\begin{array}{l}\text { C11 Sea-Related } \\
\text { Employment Personnel }\end{array}$ & Positive Index & 0.0035 & 0.0244 & 0.0140 \\
\hline & \multirow{2}{*}{$\begin{array}{l}\text { Population } \\
\text { Structure } \\
\text { (C1) }\end{array}$} & $\begin{array}{l}\text { C12 Proportion of Sea-Related } \\
\text { Employment Personnel }\end{array}$ & Positive Index & 0.0016 & 0.0212 & 0.0114 \\
\hline & & $\begin{array}{l}\text { C13 Proportion of Marine Science } \\
\text { and Technology Personnel in } \\
\text { Marine Employment }\end{array}$ & Positive Index & 0.0127 & 0.0363 & 0.0245 \\
\hline & \multirow{3}{*}{$\begin{array}{l}\text { Living } \\
\text { Standard } \\
\text { (C2) }\end{array}$} & C21 GDP Per Capita & Positive Index & 0.0352 & 0.0387 & 0.0370 \\
\hline & & C23 Urbanization Rate & Positive Index & 0.0352 & 0.0620 & 0.0486 \\
\hline & & $\begin{array}{l}\text { C31 Expenditure of Scientific } \\
\text { Research Institutions }\end{array}$ & Positive Index & 0.0113 & 0.0662 & 0.0388 \\
\hline & \multirow{2}{*}{$\begin{array}{l}\text { Research and } \\
\text { Education } \\
\text { (C3) }\end{array}$} & $\begin{array}{l}\text { C32 The Number of Patents } \\
\text { Granted for Inventions }\end{array}$ & Positive Index & 0.0252 & 0.0565 & 0.0409 \\
\hline & & $\begin{array}{l}\text { C33 The proportion of Marine } \\
\text { Research, Education and } \\
\text { Management in Service Industry }\end{array}$ & Positive Index & 0.0753 & 0.0386 & 0.0570 \\
\hline
\end{tabular}

Statistics Fact Sheet (2007-2017), Shandong Province Marine Environment Status Bulletin (2006-2016).

Due to the differences in the units of measurement of the original data, the distribution range of the original data values of each evaluation index may be very different, resulting in an inability to effectively compare the indexes. In this 
regard, this research will standardize the raw data, and the standardization formula is as follows:

$$
\text { Positive index: } x_{i j}^{\prime}=\frac{x_{i j}-x_{\min }}{x_{\max }-x_{\min }} \text { Inverse index: } x_{i j}^{\prime}=\frac{x_{\max }-x_{i j}}{x_{\max }-x_{\min }}
$$

where $x_{j}$ is the index value of item $j, x_{\max }$ is the maximum value of item $j$, $x_{\min }$ is the minimum value of item $j, x_{i j}^{\prime}$ is the standardized value.

\subsection{Evaluation Index Weight Determination}

In terms of determining the weight of the evaluation indexes, this research adopted the weight determination method with the combination of the analytic hierarchy process and the entropy evaluation method so as to reflect the actual experience of the experts and fully utilize the existing data to reflect the potential law. Under the analytic hierarchy process, the weight ratio of the three first-level indexes of marine ecological economy, marine ecological environment and marine ecological society is 12:12:6. Under the entropy evaluation method, the weight ratio of the three first-level indexes of marine ecological economy, marine ecological environment and marine ecological society can be roughly regarded as 13:9:11. Under the combination of the two methods, the weight ratio of the three first-level indexes of marine ecological economy, marine ecological environment and marine ecological society is roughly distributed as 13:11:9, which is shown in Table 1.

\section{Empirical Analysis of the Evaluation of the Construction of Marine Ecological Civilization in Shandong Province}

According to the above-mentioned evaluation index system for the construction of regional marine ecological civilization, this research systematically evaluated the construction of marine ecological civilization in Shandong Province from 2006 to 2016. Specifically, it includes the following two aspects: First, the overall evaluation of the construction level of marine ecological civilization in Shandong Province, and the analysis of each refinement index from the three dimensions of marine ecological economy, marine ecological environment and marine ecological society. Secondly, based on the coupling coordination model, analyze the coupling degree between the subsystems of marine ecological economy, marine ecological environment and marine ecological society in the construction of marine ecological civilization in Shandong Province from 2006 to 2016, and analyze the coordination level of the "economy-environment-society" development in the process of marine ecological civilization construction in Shandong Province.

\subsection{Overall Evaluation of the Construction Level of Marine Ecological Civilization in Shandong Province}

As shown in Figure 1, the overall score of the construction of marine ecological civilization in Shandong Province during 2006-2016 showed an upward trend. The growth rates of the overall score of marine ecological civilization construction 


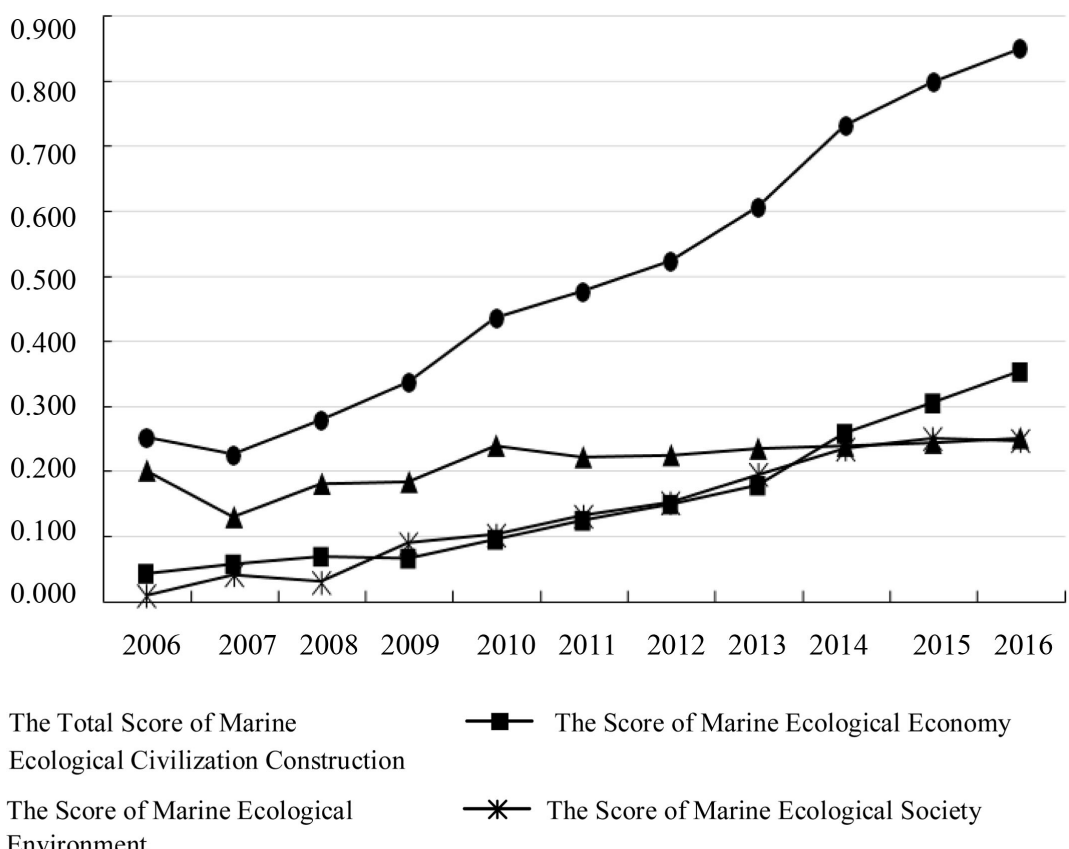

Figure 1. The overall scores of the construction of marine ecological civilization in Shandong province in 2006-2016 and the variation trend of the scores of first-level indexes.

in Shandong Province during the period of 2007-2016 were $-10.15 \%, 23.40 \%$, $20.96 \%, 29.45 \%, 9.25 \%, 10.10 \%, 15.81 \%, 20.75 \%, 9.05 \%$ and $6.54 \%$ respectively. Except for the decline in 2007, other remaining years have maintained a relatively high growth rate, with growth rates above $20 \%$ in 2008-2010. Comparing the variation trend of the three score curves of marine ecological economy, marine ecological environment and marine ecological society, the changes of marine ecological environment scores and marine ecological social scores are relatively stable, and the changes of marine ecological economy scores and the changes of overall scores of marine ecological civilization construction are basically the same.

\subsubsection{Evaluation of the Construction of Marine Ecological Economy} As shown in Figure 2, the scores of marine ecological economy in Shandong Province showed an increasing trend during the period of 2006-2016, which can be roughly divided into two stages: a steady growth period (2006-2013) and a rapid growth period (2014-2016). In these two stages, the average growth rates of scores of marine ecological economy construction in Shandong province were $22.81 \%$ and $25.60 \%$ respectively. Comparing the total scores of marine ecological economy construction during 2006-2016, the scores of the marine ecological economic scale and structure and the scores of marine ecological economic production activities, it can be found that the variation trends of the scores of marine ecological economic scale and structure and the total scores of marine ecological economy construction are basically the same, and marine ecological economic production activities have maintained a basically stable growth trend. 


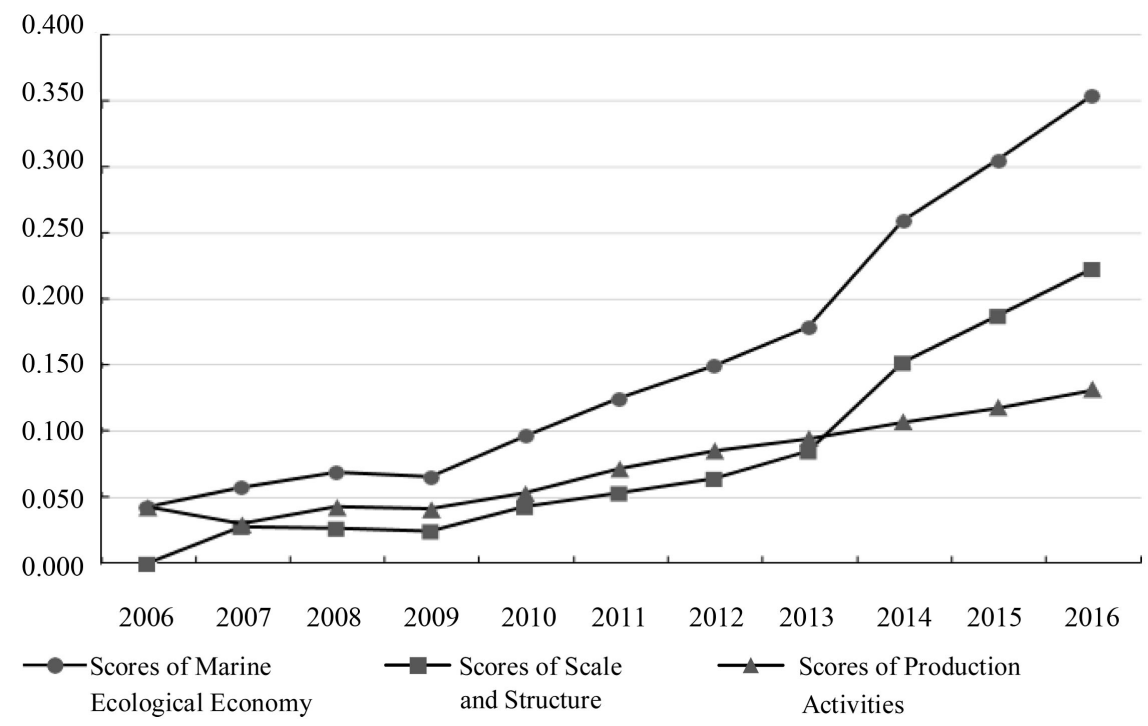

Figure 2. Scores of marine ecological economy in Shandong province during 2006-2016.

From the performance of sub-indexes, Shandong's marine GDP has been growing steadily during the period of 2006-2016, from 0.37 trillion yuan in 2006 to 1.33 trillion yuan in 2016 , with an average annual growth rate of $13.70 \%$. The proportion of marine GDP in coastal cities' GDP in Shandong has fluctuated during 2006-2016, from $32.02 \%$ in 2006 to $39.73 \%$ in 2016 . The proportion of the tertiary industry in the marine GDP of Shandong Province showed a slow increase and then a sharp rise in the period of 2006-2016. It increased from $43.10 \%$ in 2006 to $44.14 \%$ in 2012, and then increased to $51.00 \%$ in 2016 in four years. Therefore, the tertiary industry ratio of the marine GDP will largely affect the scores of marine ecological economic scale and structure. In the marine economic production activities, in addition to the downward trend of marine fishing production, the three indexes of marine aquaculture production, port cargo throughput, and tourist numbers all showed an upward trend. The production of marine aquaculture in Shandong Province increased from 3.735 million tons in 2006 to 5.278 million tons in 2016, an increase of $37.29 \%$, with an average annual growth rate of $3.22 \%$. The port cargo throughput of Shandong Province increased from 47,000 tons in 2006 to 142,900 tons in 2016, an increase of $204.04 \%$, with an average annual growth rate of $11.76 \%$. The number of tourists in coastal cities in Shandong Province increased from 82 million in 2006 to 317 million in 2016, an increase of $286.59 \%$, with an average annual growth rate of $14.48 \%$. The marine fishing production in Shandong Province decreased from $2,574,100$ tons in 2006 to $2,292,200$ tons in 2016, a decrease of $10.95 \%$, and the average annual decline rate was $1.15 \%$. It can be found that compared with the increase of the other three indexes, the decline in marine fishing production in Shandong Province is not very high. With the continuous increase in far-offshore fishing production, the marine fishing production in Shandong Province has dropped to the bottom in 2015 and showed signs of upward growth 
in 2016. The number of tourists in coastal cities of Shandong Province increased the most during the period of 2006-2016, so its contribution to the assessment of marine economic production activities was also the largest. At the same time, with the increase in far-offshore fishing production, the contribution of marine fishing production to the assessment of marine economic production activities will also increase.

\subsubsection{Evaluation of the Construction of Marine Ecological Environment} As shown in Figure 3, the marine ecological environment in Shandong Province showed an overall upward trend during 2006-2016. Among them, during 2006-2011, the score curve of marine ecological environment in Shandong Province showed a large amplitude, presenting the characteristics of "first drop and then rise": from 0.2003 in 2006, to 0.1287 in 2007, to 0.2374 in 2010 after three years of construction, and then to 0.2197 in 2011 with a slight reduction; during 2012-2016, the scores of marine ecological environment in Shandong Province showed a steady upward trend, from 0.2226 in 2012 to 0.2496 in 2016. Comparing the total scores of marine ecological environment and the pollutant emission scores and seawater quality scores under it during 2006-2016, it is found that the variation trends of seawater quality scores and total scores of marine ecological environment are basically the same, and after significant improvement in 2008 , the pollutant emission scores were basically in a stable state, with little overall change.

In terms of the performance of the sub-indexes, the amount of wastewater discharged into the sea in Shandong Province during 2006-2016 has continued to increase, from 357 million tons in 2006 to 678 million tons in 2016, an average annual increase of $6.62 \%$. The direct discharges of other pollutants such as

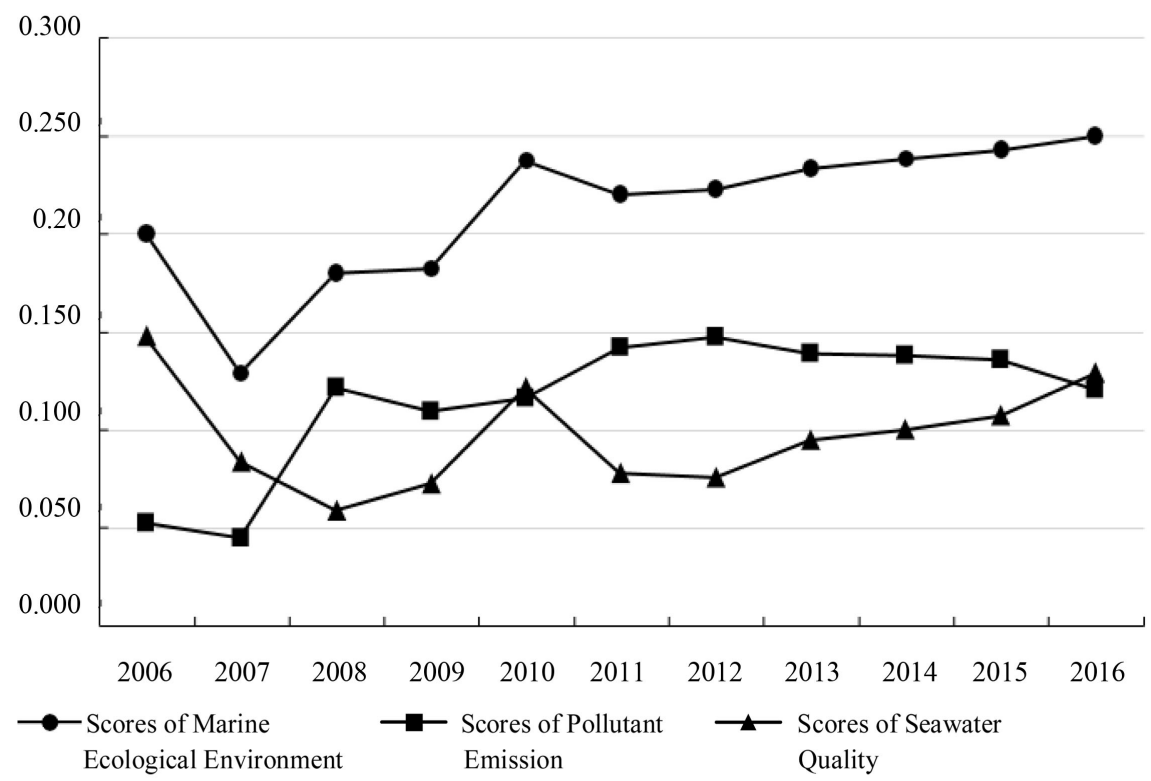

Figure 3. Scores of marine ecological environment in Shandong province during 2006-2016. 
chemical oxygen demand, petroleum, ammonia nitrogen, and total phosphorus have shown a downward trend during 2006-2016. As for the assessment of seawater quality, it is mainly measured by four indexes: "proportion of category I and II water quality", "proportion of four \& four inferior water quality", "area of red tide" and "actual coverage of green tide". Among the four indexes, except that the "proportion of category I and II water quality" is a positive index, the remaining three indexes are all inverse indexes. During the period of 2006-2016, the performance of these four evaluation indexes in the sea area of Shandong Province varies greatly, with no obvious and continuous variation trend.

\subsubsection{Evaluation of the Construction of Marine Ecological Society}

As shown in Figure 4, the scores of marine ecological society in Shandong Province grew in other years, except for the slow decline in 2008 and 2016. Comparing the total scores of the construction of marine ecological society and the population structure scores, living standards scores and science and technology support scores under it during 2006-2016, it can be roughly seen that the variation trends of science and technology support scores, living standards scores and the total scores of the construction of marine ecological society remained basically the same. The population structure scores supported the construction of marine ecological society before 2014, and then began to hinder.

In terms of the performance of sub-indexes, the number of sea-related employees in Shandong Province maintained a steady growth during the period of 2006-2016, from 4,739,300 in 2006 to 549,800 in 2016, with an average annual growth rate of $2.04 \%$. At the same time, the proportion of sea-related employees in Shandong Province to the total population of coastal cities is also rising, from $12.71 \%$ in 2006 to $14.71 \%$ in 2016 . However, the proportion of scientific and technical personnel in the sea-related employment has fluctuated upwards in 2006-2014, but there has been a large decline in 2015 and 2016, which led to a slow decline in the population structure score. GDP per capita and urbanization

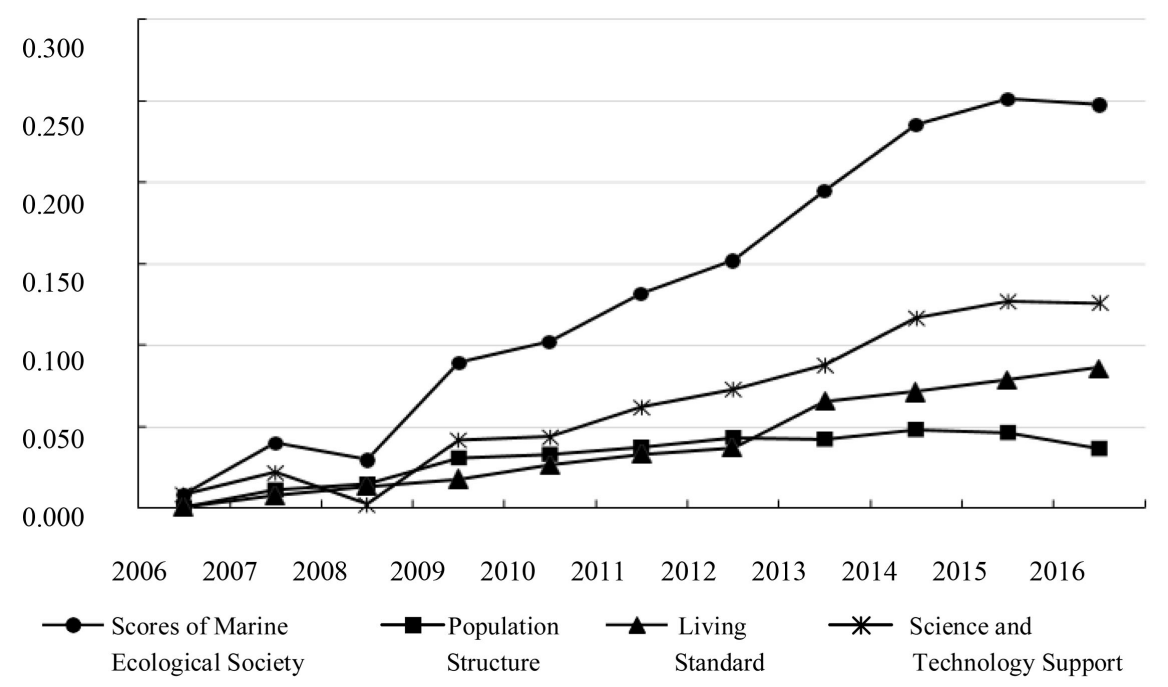

Figure 4. Scores of marine ecological society in Shandong province during 2006-2016. 
rate are two indexes for measuring living standards. The GDP per capita of coastal cities in Shandong Province showed a steady upward trend from 2006-2016, from 32,700 yuan in 2006 to 89,400 yuan in 2016, with an average annual growth rate of $10.59 \%$; the urbanization rate of coastal cities in Shandong province was $41.76 \%$ in 2006 , then increased by an average of 1.1 percentage points per year to $47.30 \%$ in 2011 . It remained at $47.30 \%$ in 2012 , but was sharply increased to $58.02 \%$ in 2013, and then maintained steady growth. By 2016, the urbanization rate of coastal cities in Shandong province reached $62.96 \%$. In the evaluation of living standards, the index weights of GDP per capita and urbanization rate are 0.0370 and 0.0486 respectively. Therefore, the urbanization rate has contributed greatly to the improvement of living standards in coastal cities of Shandong Province in recent years. The scores of science and technology support in the construction of marine ecological civilization in Shandong Province have declined in 2008, 2010 and 2016, and have maintained an upward trend in other years. From the perspective of various refinement indexes, the proportion of marine research, education and management service industry has shown an overall upward trend during the period of 2013-2016. The expenditure of scientific research institutions and the number of patents granted for inventions have shown signs of decline in recent years.

\subsection{Coupling Coordination Analysis of the Development of Marine Ecological Economy, Environment and Society in Shandong Province}

The construction of marine ecological civilization is essentially to achieve coordinated development between economic growth, environmental protection and social development. The social science research field often uses the coupling degree model to measure the degree of coordinated development between subsystems. For example, Li Xuesong et al. (2019) evaluated the economic-socialenvironment coupling and coordinated development of 109 cities above the prefecture level along the Yangtze River and Li Fanglin and Zhang Mei (2018) calculated the economic-resource-environment coupling coordination in the Yangtze River Delta urban agglomeration. When analyzing the coupling degree of two systems,

$$
C=2 \sqrt{\frac{U_{1} U_{2}}{\left(U_{1}+U_{2}\right)^{2}}}
$$

where $U_{1}, U_{2}$ represent the comprehensive evaluation index value of each subsystem. The coupling degree $C$ is between $[0,1]$. The higher the coupling degree is, the more coordinated the development between subsystems is. The lower the coupling degree is, the less coordinated the development between subsystems is and the smaller the correlation is. Considering the two extreme values of the coupling degree, the coupling degree $C$ can be divided into the following types: when $C=0$, the system coupling degree is minimal, and the systems are in independent state and developing towards disorder; when $C \in(0,0.3)$, the coupling 
is at a lower level; when $C \in(0.5,0.8)$, the coupling enters the running-in stage, and the two begin benign coupling; when $C \in(0.8,1.0)$, the system is at a high level of coupling; when $C=1$, the coupling degree of the system reaches the maximum, and all the systems are in an orderly state of mutual correlation. Of course, the coupling degree between subsystems may degenerate to the previous coupling stage due to policy reasons.

The efficacy value of each subsystem is obtained by a comprehensive evaluation of multiple measurable indexes. Since the measurement units, data sources and numerical measurement standards of each measurement index are different, it is necessary to pre-process all the measurement indexes, that is, use the efficacy functions to calculate the efficacy function values of each subsystem, and to conduct dimensionless processing and codirectional processing of measurement indexes. Subsequently, the total efficacy function of each subsystem is calculated as:

$$
U_{y}\left(u_{x y}\right)=\sum_{x=a}^{b} \lambda_{x y} u_{x y}, \sum_{x=a}^{b} \lambda_{x y}=1, \quad y=1,2,3
$$

where $\lambda_{x y}$ represents the weight of each evaluation index in each subsystem. Since the weights of each index have been calculated in Section 2, there is no need to calculate again. In the calculation of the efficacy values of each subsystem, the annual efficacy values of marine ecological economy $U_{1}$, that of marine ecological environment $U_{2}$ and that of marine ecological society $U_{3}$ can be obtained by dividing the evaluation values of each subsystem calculated in Section 2.2 by their weight values of $0.3891,0.3393$ and 0.2722 respectively, which is showing in Table 2.

Coupling degree $C$ is a measurement of the association degree between systems, but it is difficult to compare the comprehensive index of the two systems. It is possible that the two systems have a low level of development but a high

Table 2. Efficacy values of each subsystem in the construction of marine ecological civilization in Shandong province from 2006 to 2016.

\begin{tabular}{cccc}
\hline Year & $\begin{array}{r}\text { Marine Ecological } \\
\text { Economy } U_{1}\end{array}$ & $\begin{array}{c}\text { Marine Ecological } \\
\text { Environment } U_{2}\end{array}$ & $\begin{array}{c}\text { Marine Ecological } \\
\text { Society } U_{3}\end{array}$ \\
\hline 2006 & 0.1086 & 0.5904 & 0.0286 \\
2007 & 0.1461 & 0.3793 & 0.1448 \\
2008 & 0.1763 & 0.5308 & 0.1062 \\
2009 & 0.1673 & 0.5361 & 0.3262 \\
2010 & 0.2454 & 0.6997 & 0.3739 \\
2011 & 0.3193 & 0.6477 & 0.4808 \\
2012 & 0.3820 & 0.6562 & 0.5567 \\
2013 & 0.4577 & 0.6874 & 0.7133 \\
2014 & 0.6637 & 0.7020 & 0.8621 \\
2015 & 0.7815 & 0.7155 & 0.9202 \\
2016 & 0.9069 & 0.7357 & 0.9074 \\
\hline
\end{tabular}


degree of coupling, which deviates from the reality. To this end, based on the research results of relevant scholars, and in order to better reflect the coupling coordination between the two systems, a coupling coordination degree model is constructed to analyze the coordinated development level of the two systems. The formula is:

$$
D=\sqrt{C \times T}
$$

where $T=\alpha U_{1}+\beta U_{2}$. In the formula, $D$ is the coupling coordination degree, $C$ is the coupling degree, and $T$ is the comprehensive evaluation index of the two systems. $\alpha, \beta$ is the undetermined coefficients. According to relevant research results, the value of $\alpha$ and $\beta$ is 0.5 , and 0.5 is regarded as the dividing line of system maladjustment and coordination. Where $D \in(0,1)$, and the coordination degree can be divided into the following four types: when $D \in(0,0.3)$, the system is extremely misaligned coupling; when $D \in(0.3,0.5)$, the system is low coordinated coupling; when $D \in(0.5,0.8)$, the system is moderately coordinated coupling; when $D \in(0.8,1.0)$, the system is a highly coordinated coupling.

\subsubsection{Coupling Analysis of Marine Ecological Economy and Marine Ecological Environment}

Table 3 shows the calculation results of the efficacy value, coupling degree and coupling coordination degree of marine ecological economy and marine ecological environment in Shandong Province during 2006-2016.

In terms of efficacy values, the range of efficacy values of marine ecological economy in Shandong Province is [0.1086, 0.9069], with an average value of 0.3959. The range of efficacy values of marine ecological environment in Shandong Province is $[0.3793,0.7357]$, with an average value of 0.6255 . It can be seen that during the period of 2006-2016, the efficacy value of marine ecological economy and marine ecological environment in Shandong Province showed an overall upward trend, and the efficacy value of marine ecological economy in Shandong Province increased even more. Also, during the period of 2006-2014, the efficacy value of marine ecological economy in Shandong Province has always been lower than that of marine ecological environment. Only after 2015, the efficacy value of marine ecological economy in Shandong Province began to exceed that of marine ecological environment. This indicates that during the period of 2006-2014, the marine ecological environment of Shandong Province was in a dominant position in the coupling relationship between marine ecological economy and marine ecological environment. In 2015 and after, the marine ecological economy of Shandong province has gradually taken a dominant position in the coupling relationship between marine ecological economy and marine ecological environment, and has a trend of continuous expansion.

From the perspective of coupling degree, the coupling level of marine ecological economy and marine ecological environment in Shandong Province increased rapidly from the running-in stage to the highly coordinated level during 2006-2007. Since then, after years of adjustment during 2008-2010, the coupling degree value has stabilized above 0.9 and has steadily increased. After 2014, it 
Table 3. Calculation results of coupling relationship between marine ecological economy and marine ecological environment in Shandong province from 2006 to 2016.

\begin{tabular}{|c|c|c|c|c|c|c|}
\hline Year & $\begin{array}{c}\text { Marine } \\
\text { Ecological } \\
\text { Economy } U_{1}\end{array}$ & $\begin{array}{c}\text { Marine } \\
\text { Ecological } \\
\text { Environment } \\
\mathrm{U}_{2}\end{array}$ & $\begin{array}{l}\text { Coupling } \\
\text { Degree } \\
\text { C Value }\end{array}$ & $\begin{array}{l}\text { Coupling } \\
\text { Degree } \\
\text { C Phase }\end{array}$ & $\begin{array}{c}\text { Coupling } \\
\text { Coordination } \\
\text { Degree D } \\
\text { Value }\end{array}$ & $\begin{array}{c}\text { Coupling } \\
\text { Coordination } \\
\text { Degree D Leve }\end{array}$ \\
\hline 2006 & 0.1086 & 0.5904 & 0.7245 & Running-in & 0.5032 & $\begin{array}{l}\text { Moderately } \\
\text { Coordinated }\end{array}$ \\
\hline 2007 & 0.1461 & 0.3793 & 0.8961 & High-Level & 0.4852 & $\begin{array}{c}\text { Low } \\
\text { Coordinated }\end{array}$ \\
\hline 2008 & 0.1763 & 0.5308 & 0.8653 & High-Level & 0.5531 & $\begin{array}{l}\text { Moderately } \\
\text { Coordinated }\end{array}$ \\
\hline 2009 & 0.1673 & 0.5361 & 0.8515 & High-Level & 0.5472 & $\begin{array}{l}\text { Moderately } \\
\text { Coordinated }\end{array}$ \\
\hline 2010 & 0.2454 & 0.6997 & 0.8768 & High-Level & 0.6437 & $\begin{array}{l}\text { Moderately } \\
\text { Coordinated }\end{array}$ \\
\hline 2011 & 0.3193 & 0.6477 & 0.9406 & High-Level & 0.6744 & $\begin{array}{l}\text { Moderately } \\
\text { Coordinated }\end{array}$ \\
\hline 2012 & 0.3820 & 0.6562 & 0.9645 & High-Level & 0.7076 & $\begin{array}{l}\text { Moderately } \\
\text { Coordinated }\end{array}$ \\
\hline 2013 & 0.4577 & 0.6874 & 0.9797 & High-Level & 0.7489 & $\begin{array}{l}\text { Moderately } \\
\text { Coordinated }\end{array}$ \\
\hline 2014 & 0.6637 & 0.7020 & 0.9996 & High-Level & 0.8262 & $\begin{array}{c}\text { Highly } \\
\text { Coordinated }\end{array}$ \\
\hline 2015 & 0.7815 & 0.7155 & 0.9990 & High-Level & 0.8647 & $\begin{array}{c}\text { Highly } \\
\text { Coordinated }\end{array}$ \\
\hline 2016 & 0.9069 & 0.7357 & 0.9946 & High-Level & 0.9038 & $\begin{array}{c}\text { Highly } \\
\text { Coordinated }\end{array}$ \\
\hline
\end{tabular}

has remained above 0.99 , maintaining a high level of coupling relationship.

From the perspective of coupling coordination degree, the coupling coordination curve of marine ecological economy and marine ecological environment in Shandong Province is in a growth stage except for a slight decline in 2007 and 2009. In 2010-2011, the coupling coordination degree is in the range of $(0.6,0.7)$; in 2012-2013, the coupling coordination degree is in the range of $(0.7-0.8)$; in 2014-2015, the coupling coordination degree is in the range of $(0.8-0.9)$; in 2016, the coupling coordination value of marine ecological economy and marine ecological environment in Shandong Province is above 0.9. This indicates that the marine ecological economy and marine ecological environment of Shandong Province are developing in a mutually reinforcing direction.

\subsubsection{Coupling Analysis of Marine Ecological Society and Marine Ecological Environment}

Table 4 shows the calculation results of the efficacy value, coupling degree and coupling coordination degree of marine ecological society and marine ecological environment in Shandong Province during 2006-2016. 
Table 4. Calculation results of the coupling relationship between marine ecological society and marine ecological environment in Shandong province from 2006 to 2016.

\begin{tabular}{|c|c|c|c|c|c|c|}
\hline Year & $\begin{array}{c}\text { Marine } \\
\text { Ecological } \\
\text { Society } U_{1}\end{array}$ & $\begin{array}{c}\text { Marine } \\
\text { Ecological } \\
\text { Environment } \\
\mathrm{U}_{2}\end{array}$ & $\begin{array}{l}\text { Coupling } \\
\text { Degree } \\
\text { C Value }\end{array}$ & $\begin{array}{l}\text { Coupling } \\
\text { Degree } \\
\text { C Phase }\end{array}$ & $\begin{array}{c}\text { Coupling } \\
\text { Coordination } \\
\text { Degree D } \\
\text { Value }\end{array}$ & $\begin{array}{c}\text { Coupling } \\
\text { Coordination } \\
\text { Degree D } \\
\text { Level }\end{array}$ \\
\hline 2006 & 0.0286 & 0.5904 & 0.4200 & Antagonistic & 0.3605 & $\begin{array}{c}\text { Low } \\
\text { Coordinated }\end{array}$ \\
\hline 2007 & 0.1448 & 0.3793 & 0.8943 & High-Level & 0.4841 & $\begin{array}{c}\text { Low } \\
\text { Coordinated }\end{array}$ \\
\hline 2008 & 0.1062 & 0.5308 & 0.7453 & Running-in & 0.4872 & $\begin{array}{c}\text { Low } \\
\text { Coordinated }\end{array}$ \\
\hline 2009 & 0.3262 & 0.5361 & 0.9699 & High-Level & 0.6467 & $\begin{array}{l}\text { Moderately } \\
\text { Coordinated }\end{array}$ \\
\hline 2010 & 0.3739 & 0.6997 & 0.9528 & High-Level & 0.7152 & $\begin{array}{l}\text { Moderately } \\
\text { Coordinated }\end{array}$ \\
\hline 2011 & 0.4808 & 0.6477 & 0.9890 & High-Level & 0.7470 & $\begin{array}{l}\text { Moderately } \\
\text { Coordinated }\end{array}$ \\
\hline 2012 & 0.5567 & 0.6562 & 0.9966 & High-Level & 0.7774 & $\begin{array}{l}\text { Moderately } \\
\text { Coordinated }\end{array}$ \\
\hline 2013 & 0.7133 & 0.6874 & 0.9998 & High-Level & 0.8368 & $\begin{array}{c}\text { Highly } \\
\text { Coordinated }\end{array}$ \\
\hline 2014 & 0.8621 & 0.7020 & 0.9947 & High-Level & 0.8820 & $\begin{array}{c}\text { Highly } \\
\text { Coordinated }\end{array}$ \\
\hline 2015 & 0.9202 & 0.7155 & 0.9921 & High-Level & 0.9008 & $\begin{array}{c}\text { Highly } \\
\text { Coordinated }\end{array}$ \\
\hline 2016 & 0.9074 & 0.7357 & 0.9945 & High-Level & 0.9039 & $\begin{array}{c}\text { Highly } \\
\text { Coordinated }\end{array}$ \\
\hline
\end{tabular}

In terms of efficacy values, the range of efficacy values of marine ecological society in Shandong Province is [0.0286, 0.9074], with an average value of 0.4928 . The range of efficacy values of marine ecological environment in Shandong Province is $[0.3793,0.7357]$, with an average value of 0.6255 . It can be seen that during the period of 2006-2016, the efficacy value of marine ecological economy and marine ecological environment in Shandong Province showed an overall upward trend, and the efficacy value of marine ecological society in Shandong Province increased even more. Similar to the relationship between the efficacy value of marine ecological economy and the efficacy value of marine ecological environment in Shandong Province, the efficacy value of marine ecological society in Shandong Province has been lower than the efficacy value of marine ecological environment during 2006-2013, but after 2014, the efficiency value of marine ecological society in Shandong Province began to exceed that of marine ecological environment. This indicates that the marine ecological environment of Shandong Province was in a dominant position in the coupling relationship between marine ecological society and marine ecological environment 
during the period of 2006-2013. In 2014 and after, the marine ecological society of Shandong Province is gradually in a dominant position in the coupling relationship between marine ecological society and marine ecological environment. However, in 2016, the efficacy value of marine ecological society in Shandong Province showed signs of decline, indicating that its dominant role may face a weakening trend.

From the perspective of coupling degree, the coupling level of marine ecological society and marine ecological environment in Shandong Province increased rapidly from the antagonistic stage to the highly coordinated stage during 2006-2007. After declining to the running-in stage during 2008-2009, it rose back to a high-level adjustment process, maintaining a stable coupling degree value above 0.9 and keeping steadily increasing. After 2012, it has remained above 0.99 , maintaining a high level of coupling relationship.

From the perspective of coupling coordination degree, the coupling coordination level of marine ecological economy and marine ecological environment in Shandong Province during 2006-2016 experienced a three-year low coordination period, a four-year moderate coordination period, and an increasingly high coordination period, and the coupling coordination value reached above 0.9 during 2015-2016. This indicates that the development of marine ecological society and the development of marine ecological environment in Shandong Province are moving towards mutual promotion.

\subsubsection{Coupling Analysis of Marine Ecological Economy and Marine Ecological Society}

Table 5 shows the calculation results of the efficacy value, coupling degree and coupling coordination degree of marine ecological economy and marine ecological society in Shandong Province during 2006-2016.

From the perspective of efficacy value, the range of efficacy values of marine ecological economy in Shandong Province is [0.1086, 0.9069], with an average value of 0.3959 . The range of efficacy values of marine ecological society in Shandong Province is $[0.0286,0.9074]$, with an average value of 0.4928 . It can be seen that during the period of 2006-2016, the efficacy value of marine ecological economy and marine ecological society in Shandong Province showed an overall upward trend. Different from the comparison between the efficacy value of marine ecological economy and marine ecological environment in Shandong Province and the comparison between the efficacy value of marine ecological society and marine ecological environment in Shandong Province, the efficacy value of marine ecological economy and marine ecological society in Shandong Province both increased greatly from 2006 to 2016. During the period of 2006-2008, the efficacy value of marine ecological economy in Shandong Province was higher than that of marine ecological society. During the period of 2009-2015, the efficacy value of marine ecological society in Shandong Province was higher than that of marine ecological economy. In 2016, the efficacy value of marine ecological economy in Shandong province was again slightly ahead of that of marine 
Table 5. Calculation results of the coupling relationship between marine ecological economy and marine ecological society in Shandong province from 2006 to 2016.

\begin{tabular}{|c|c|c|c|c|c|c|}
\hline Year & $\begin{array}{c}\text { Marine } \\
\text { Ecological } \\
\text { Economy } \\
\text { U1 }\end{array}$ & $\begin{array}{c}\text { Marine } \\
\text { Ecological } \\
\text { Society U3 }\end{array}$ & $\begin{array}{c}\text { Coupling } \\
\text { Degree } \\
\text { C Value }\end{array}$ & $\begin{array}{l}\text { Coupling } \\
\text { Degree } \\
\text { C Phase }\end{array}$ & $\begin{array}{c}\text { Coupling } \\
\text { Coordination } \\
\text { Degree D } \\
\text { Value }\end{array}$ & $\begin{array}{c}\text { Coupling } \\
\text { Coordination } \\
\text { Degree D } \\
\text { Level }\end{array}$ \\
\hline 2006 & 0.1086 & 0.0286 & 0.8126 & High-Level & 0.2361 & $\begin{array}{l}\text { Extremely } \\
\text { Disordered }\end{array}$ \\
\hline 2007 & 0.1461 & 0.1448 & 0.9999 & High-Level & 0.3814 & $\begin{array}{c}\text { Low } \\
\text { Coordinated }\end{array}$ \\
\hline 2008 & 0.1763 & 0.1062 & 0.9687 & High-Level & 0.3699 & $\begin{array}{c}\text { Low } \\
\text { Coordinated }\end{array}$ \\
\hline 2009 & 0.1673 & 0.3262 & 0.9467 & High-Level & 0.4833 & $\begin{array}{c}\text { Low } \\
\text { Coordinated }\end{array}$ \\
\hline 2010 & 0.2454 & 0.3739 & 0.9782 & High-Level & 0.5504 & $\begin{array}{l}\text { Moderately } \\
\text { Coordinated }\end{array}$ \\
\hline 2011 & 0.3193 & 0.4808 & 0.9794 & High-Level & 0.6260 & $\begin{array}{l}\text { Moderately } \\
\text { Coordinated }\end{array}$ \\
\hline 2012 & 0.3820 & 0.5567 & 0.9825 & High-Level & 0.6791 & $\begin{array}{l}\text { Moderately } \\
\text { Coordinated }\end{array}$ \\
\hline 2013 & 0.4577 & 0.7133 & 0.9759 & High-Level & 0.7559 & $\begin{array}{l}\text { Moderately } \\
\text { Coordinated }\end{array}$ \\
\hline 2014 & 0.6637 & 0.8621 & 0.9915 & High-Level & 0.8698 & $\begin{array}{c}\text { Highly } \\
\text { Coordinated }\end{array}$ \\
\hline 2015 & 0.7815 & 0.9202 & 0.9967 & High-Level & 0.9209 & $\begin{array}{c}\text { Highly } \\
\text { Coordinated }\end{array}$ \\
\hline 2016 & 0.9069 & 0.9074 & 0.9999 & High-Level & 0.9524 & $\begin{array}{c}\text { Highly } \\
\text { Coordinated }\end{array}$ \\
\hline
\end{tabular}

ecological society. It is worth noting that the difference between the efficacy values of marine ecological economy and marine ecological society in Shandong province in 2006-2016 is not as big as the difference between that of marine ecological economy and marine ecological environment, the former being more of a spiral upward development trend.

From the perspective of coupling degree, the coupling level of marine ecological economy and marine ecological society in Shandong Province has been in a high-level coupling stage during 2006-2016, and its coupling value has remained above 0.95 in 2010 and beyond.

From the perspective of coupling coordination degree, the coupling coordination level of marine ecological economy and marine ecological society in Shandong Province in 2006-2016 experienced a one-year extremely disordered period, a three-year low coordination period, a four-year medium coordination period, and then an increasingly high coordination period. In 2015-2016, the coupling coordination value reached above 0.9 . 


\section{Research Conclusions}

\subsection{Evaluation and Analysis of the Construction of Marine Ecological Civilization in Shandong Province}

During the period of 2006-2016, the construction of marine ecological civilization in Shandong Province is on the rise. From the perspective of the increase in scores of each subsystem, the development of marine ecological society has the largest increase, followed by the development of marine ecological economy, and the development of marine ecological environment is relatively slow. In terms of marine ecological and social development, the scores of marine science and technology development represented by the expenditure of marine scientific research institutions, the proportion of marine research, education and management in service industry and the number of patents granted for marine inventions, etc. make the largest contribution to its development. In terms of the development of marine ecological economy, the scale and structure of the marine economy contributed the most to its growth. The sustained increase in the proportion of the tertiary industry in the marine economy has a prominent role in promoting the improvement of the score of marine economic development. The marine fishing production declined along with the continuous decline of offshore fishing production, which led to an inhibiting effect on the increase in the score of marine economic development. However, with the increase of far-offshore fishing production in Shandong Province in recent years, this effect will gradually disappear. In terms of the development of marine ecological environment, after the fluctuation period of 2006-2011, its score began to increase steadily. The continuous improvement of seawater quality promoted its score increase, while the continuous increase of marine pollutant emissions inhibited its score increase.

\subsection{Coupling Coordination Analysis of the Development of Marine Ecological Economy, Environment and Society in Shandong Province}

The coupling coordination values of the three paired subsystems of marine ecological economy plus marine ecological environment, marine ecological society plus marine ecological environment and marine ecological economy plus marine ecological society in Shandong Province have all basically gone through the development process from low coordination to moderate coordination, and finally to high coordination during 2006-2016. By 2016, the coupling coordination values of the three paired subsystems of marine ecological economy plus marine ecological environment, marine ecological society plus marine ecological environment and marine ecological economy plus marine ecological society in Shandong Province have reached $0.9038,0.9039$ and 0.9524 respectively. The reason is that the efficacy value of marine ecological environment in Shandong Province is relatively low. In the future, the construction of marine ecological civilization in Shandong Province should focus on improving the quality of its 
marine ecological environment.

\section{Conflicts of Interest}

The author declares no conflicts of interest regarding the publication of this paper.

\section{References}

Chen, F. G., Wang, J. K., \& Jiang, J. L. (2014). Analysis of Marine Ecological Civilization. Marine Development and Management, 31, 70-76.

Chen, J. H. (2009). Reflections on the Construction of Marine Ecological Civilization. Marine Development and Management, 26, 40-42.

Du, Y., \& Qin, W. S. (2019). Evaluation of Construction Level of National Marine Ecological Civilization Construction Demonstration Zone. Marine Development and Management, 36, 7-13.

Li, F. L., \& Zhang, M. (2018). Coupling and Coordination Differences of the Economy-Resources-Environment System in the Yangtze River Delta Megalopolis. East China Economic Management, 32, 59-65.

Li, X. S., Long, X. X., \& Qi, X. X. (2019). Dynamic Evolution and Analysis of Coupling Development of Economy, Society and Environment in Yangtze River Economic Belt. Resources and Environment in the Yangtze Basin, 28, 505-516.

Liu, J. Z. (2007). Strategic Thinking on Building Marine Ecological Civilization. China Forum Today, 12, 44-46.

Qin, W. S., Yang, H. D., Li, J. N., \& Zhang, M. (2016). Evaluation System and Level Measurement of Marine Ecological Civilization City Construction around the Bohai Sea. Science and Technology Review, 34, 58-63.

Sun, J. F., Qin, W. S., Sun, H. Y., Li, S. T., \& Du, Y. (2018). Evaluation System and Level Measurement of Marine Ecological Civilization Construction in China's Coastal Cities. Economic Geography, 38, 19-28.

Sun, Q., Yu, D. T., Ju, M. W., Jin, S. C., Wang, W., Guan, W., \& Guan, X. J. (2017). Construction of Marine Ecological Civilization Performance Evaluation Index System. Marine Development and Management, 34, 3-8. 